\title{
Assessment of genetic parameters of degradability in maize grains due to indentation scores
}

\author{
Livia Maria Chamma Davide ${ }^{1}$; Magno Antônio Patto Ramalho²*; Ulisses José de Figueiredo; \\ João Cândido de Souza ${ }^{2}$ \\ ${ }^{1}$ UFLA - Programa de Pós-Graduação em Genética e Melhoramento de Plantas. \\ ${ }^{2}$ UFLA - Depto. de Biologia, C.P. 3037 - 37200-000 - Lavras, MG - Brasil. \\ *Corresponding author < magnoapr@dbi.ufla.br>
}

\begin{abstract}
Maize (Zea mays L.) cultivars with dent grains present higher starch and dry matter ruminal degradability than those with flint grains. This study aimed to assess genetic parameters of degradability in maize grains of different textures and to verify whether there is an association between grain indentation score and ruminal dry matter (RDM) degradability. The evaluated progenies were obtained from the cross between the varieties Cristal (flint) and Cunha (dent), previously selected for grain hardness. Progenies were evaluated for an indentation score using a visual grading scale ranging from 1 (flint) to 5 (dent). To assess the RDM degradability, $5 \mathrm{~g}$ were cut into halves, weighed (five grams), stored in bags made of 100\% "failet" cloth and incubated for $24 \mathrm{~h}$ in the rumen of three ruminally cannulated cows. There was genetic variability for RDM degradability and heritability was $46 \%$, indicating the possibility of success using a selection. There was no association between indentation score and RDM degradability percentage; thus, visual evaluation not always reflects grain hardness per se since it indicates the pericarp aspect but not the endosperm constitution.
\end{abstract}

Key words: grain hardness, ruminal dry matter degradability, heritability

\section{Estimativas de parâmetros genéticos da degradabilidade de grãos de milho diferindo em escore de identação}

\begin{abstract}
RESUMO: Cultivares de milho (Zea mays L.) com grãos do tipo dentado possuem maior porcentagem de amido e degradabilidade ruminal da matéria seca do que os com grãos do tipo duro. Estimaram-se parâmetros genéticos da degradabilidade de grãos de milho com diferentes texturas e verificou-se se ocorre associação entre o escore de identação dos grãos visualmente avaliados e a degradabilidade in situ da matéria seca (DISMS). Foram avaliadas progênies oriundas do cruzamento entre a variedade Cristal, de grãos duros, e a variedade Cunha de grãos dentados, previamente selecionadas para a dureza dos grãos. As progênies foram avaliadas com relação ao escore de identação por meio de uma escala visual de notas variando de 1 (duro) a 5 (mole). Para a avaliação da DISMS os grãos foram cortados ao meio, pesados $5 \mathrm{~g}$ colocados em saquinhos de tecido "failet" e incubados no rúmen, por $24 \mathrm{~h}$, em três vacas portadoras de cânula ruminal. Há variabilidade genética para a DISMS, com herdabilidade de $46 \%$, indicando ser possível o sucesso com a seleção. Não há associação entre o escore de identação e a porcentagem de DISMS. Assim, a avaliação visual nem sempre reflete a dureza per se dos grãos, pois o que se vê é o aspecto do pericarpo e não a constituição do endosperma.

Palavras-chave: dureza dos grãos, degradabilidade ruminal, herdabilidade
\end{abstract}

\section{Introduction}

In the south of Minas Gerais State, Brazil, the most traditional farmers insist on using varieties despite the great availability of more productive hybrid cultivars in the market. These varieties are mostly used in animal feeding either as silage or as grains. There is a great variation among them concerning grain texture, since some varieties are excessively hard (flint) such as Cristal maize, as others are highly soft (dent) such as Cunha variety. Maize (Zea mays L.) cultivars of dent grains have higher starch and dry matter ruminal degradability than those of flint grains (Ngonyamo-Majee et al., 2008; Pereira et al., 2004).

Different progenies in grain hardness and, probably, in degradability can be obtained from the cross between Cristal and Cunha varieties, contributing to elucidate important genetic parameters for the success of maize breeding programs with grains of favorable texture for animal feeding. Thus, this study aimed to assess genetic parameters of maize grain degradability and to verify whether there is an association between the indentation score of visually evaluated grains and ruminal dry matter (DM) degradability.

\section{Material and Methods}

The experiment was carried out from September 2006 to July 2008 in Lavras, Minas Gerais State, Brazil (21 ${ }^{\circ} 45^{\prime}$ S; $45^{\circ} 00^{\prime}$ W, $918 \mathrm{~m}$ a.s.l.). Two maize varieties were tested, Cristal and Cunha, which are contrasting in grain hardness and do not segregate for the studied trait (Table 1). In the crop cycle 2006/07, around 50 plants of each variety were crossed to produce $\mathrm{F}_{1}$ seeds with Cristal and Cunha cytoplasm. The latter were sown in February 2007 and subjected to autofecundation to produce $\mathrm{F}_{2}$ seeds. At the end of that same 
Table 1 - Characteristics of the maize cultivars used in the evaluation of ruminal dry matter degradability.

\begin{tabular}{lcc}
\hline Characteristic & Cristal & Cunha \\
\hline Color & white & yellow \\
Format & round & flat \\
Density & high & low \\
Indentation & absent & present \\
Vitreousness & high & low \\
\hline
\end{tabular}

year, $F_{2}$ seeds were subjected to autofecundation and ears were individually harvested, obtaining the progenies $\mathrm{F}_{2: 3}$ concerning the embryo and the endosperm. A sample of seeds from the central region of an ear from each genitor and from all $158 \mathrm{~F}_{2: 3}$ progenies $(87$ Cristal $\times$ Cunha and 71 Cunha $\times$ Cristal) constituted the experimental material used in this work. The samples were stored under approximately 13\% humidity.

Grain samples were employed to evaluate the indentation scores by using a grading scale ranging from 1 to 5 , in which 1 indicates a grain presenting no indentation and round smooth upper extremity, and 5 a grain presenting marked indentation and rough upper extremity. Within the sample, there was no apparent variation of the grain indentation score; such variation was only observed among progenies.

Another evaluated trait was the ruminal DM (RDM) degradability. A preliminary experiment was carried out to verify the best RDM degradability evaluation strategy, i.e. half or ground grains. Grains from the varieties Cristal and Cunha were tested, and the hybrid P30F33 (flint and without indentation) and the variety Asteca (dent and with indentation) were used as checks. Grains of each treatment were cut into halves using a "tablet cutter" or ground in a mill containing a $5 \mathrm{~mm}$ sieve. Data were evaluated in a four (cultivars) $\times$ two (grain processing method) factorial arrangement, with three reps.

A fistulated Jersey cow was used to assess RDM degradability percentage. This animal was subjected to a 15day adaptation period, during which it was fed silage, maize and corn meal diet in order to obtain good ruminal conditions for the study. The same diet was kept during the maize sample incubation in the animal.

Maize was previously dried in an oven, at $65^{\circ} \mathrm{C}$, for $72 \mathrm{~h}$ and placed in a desiccator until weighing $(5 \mathrm{~g})$ for each treatment. Then, samples were stored in bags made of "faillet" cloth $(100 \%$ polyester $)$. Bags'dimension was $90 \times 150 \mathrm{~mm}$, corresponding to $0.185 \mathrm{mg} \mathrm{mm}^{-2}$ ratio. The bags had their edges closed by an electrical sealing machine. Once closed, the bags were weighed in a precision analytical scale and oven stored.

On the incubation day, bags were placed inside a tulle bag together with weights to keep them immersed in the rumen. Then, they were incubated in the animal for $24 \mathrm{~h}$. After being removed from the rumen, the bags were immediately placed in cold water to stop dry matter degradation.
They were washed with slight agitation in a tank system with a spinning wheel for $10 \mathrm{~min}$, and the water was constantly renewed until it was transparent. The bags were then stored in an oven, at $65^{\circ} \mathrm{C}$, for $72 \mathrm{~h}$. After a constant weight was obtained the bags were weighed. The weight difference between this weighing and the one done before incubation was used to calculate the quantity of dry matter degraded in the rumen, expressed as a percentage.

Analysis of variance, followed by Scott and Knott (1974) test, at 5\%, was done using GENES software (Cruz, 2001). The following statistical model was employed for analysis: $Y_{i j}=m+p_{i}+e_{i j}$, where: $Y_{i j}$ : value evaluated in the $\mathrm{i}$-th treatment in the $\mathrm{j}$-th replicate, $m$ : general mean, $p_{i}$ : effect of the $\mathrm{i}$ th cultivar, and $e_{i: \text { : }}$ random error.

Based on the determination of the best processing method, a second experiment was carried out to assess the RDM degradability. The genetic material used included the varieties Cristal and Cunha, $158 \mathrm{~F}_{2: 3}$ progenies and four checks, two of dent grains (AG1051, AG5011) and two of flint grains (P30F33, XB8010). Grains from the intermediate part of these ears were longitudinally cut into two equal parts using a "tablet cutter" and employed in the RDM degradability assay. The preparation of samples and animals, the conduction of the experiment and the calculation of RDM degradability percentage were done as previously described.

Three non-lactating, non-pregnant, ruminally cannulated cows were used. Two of them were of Jersey and one of Nelore breed. The 158 progenies were divided into three groups at incubation. In the first and second groups, 60 progenies were evaluated and in the third, 38 progenies and the two genitors. Four controls, AG1051, AG5011, P30F33 and XB8010, were common to all experiments. The same treatments were incubated in the different animals every day.

Data on degradable dry matter percentage were subjected to cluster analysis in randomized blocks, with common treatments, using the GENES software (Cruz, 2001). The adopted statistical model was: $Y_{c i j k}=m+a_{k}+p_{c(k)}+v_{j(k)}+t+(a t)_{i k}+$ $e_{c i j k}$ where: $Y_{c i j k}$ : value obtained in the c-th progeny in $\mathrm{i}$-th treatment in the $\mathrm{j}$-th replicate of the experiment $\mathrm{k} ; m$ : general mean; $a_{k}$ : effect of the k-th experiment; $p_{c(k)}$ : effect of the c-th progeny in the k-th experiment; $v_{j(k)}$ : effect of the $j$-th block in the k-th experiment; t: effect of common treatments; $(a t)_{i k}$ : effect of the interaction between the common treatment and the experiment; and $e_{c i j k}$ : random error.

Expectations of mean squares were used to assess the genetic variance among progenies, the confidence intervals associated with the variance-component estimates, the broadsense heritability on a progeny mean, and the upper and lower limits of heritability estimates, with confidence of $1-$ $\alpha=0.95$ (Knapp et al., 1985).

\section{Results and Discussion}

As expected, the RDM degradability of ground grains was higher than that of grains cut into halves (Table 2). On average, the degradability of ground grains was 3.03-fold higher than that of cut grains. 
Different grain processing methods have been frequently reported in references (Passini et al., 2004; Philippeau and Michalet-Doreau, 1998; Teixeira et al., 1996). In all studies, the authors concluded that the RDM degradability of ground grains, as observed in this study, is higher than that of broken grains. The RDM degradability soluble fraction is equal for both flocculated and finely ground maize and has lower value when the grains are broken (Lykos and Varga, 1995). Grinding increases the grain surface because of the action of digestive enzymes, improving nutrient digestibility (Monticelli et al., 1996). Thus, differences are more difficult to detect in ground than in cut or broken grains. However, RDM degradability classification barely differed among cultivars concerning the grain processing methods (Table 2). It was higher for Cunha variety and lower for Cristal variety and P30F33 hybrid. Thus, the differences among progenies in the present study for grains cut into halves reflect the genotypic variation in RDM degradability.

Table 2 - Mean percentage of ruminal dry matter (DM) degradability for grains cut into halves and ground to $5 \mathrm{~mm}$.

\begin{tabular}{lcc}
\hline Treatment & cut into halves & ground to $5 \mathrm{~mm}$ \\
\hline Cristal & $10.1 \mathrm{a}$ & $37.8 \mathrm{a}$ \\
P30F33 & $11.4 \mathrm{a}$ & $36.0 \mathrm{a}$ \\
Cunha & $14.4 \mathrm{~b}$ & $45.0 \mathrm{~b}$ \\
Asteca & $16.2 \mathrm{~b}$ & $39.0 \mathrm{a}$ \\
Mean & 13.0 & 39.4 \\
\hline
\end{tabular}

Means followed by different letters in the same column are different (Scott and Knott (1974) test, $p<0.05)$.
The chemical composition of maize grain starch interferes with its availability for the rumen enzymatic hydrolysis (McAllister et al., 1993 and Philippeau et al., 2000). The variations in the ruminal degradation of maize starch of different vitreousness are strictly related to protein distribution in the endosperm. Thus, maize grains cut into halves are more effective in separating genotypes since they evidence differences concerning hardness due to the lower separation of starch granules of the protein matrix. On the other hand, starch granules are less protected by the protein matrix in ground grains. Consequently, they are more available to the action of microorganisms in the rumen. Grain moisture can also affect degradability (Corrêa et al., 2003; Pereira et al., 2004). However, as the used grains were dried and all ears were stored at $13 \%$ humidity, it was assumed no differences among grain moistures.

The summary of the variance analysis for RDM degradability percentage of genitors and progenies, incubated for $24 \mathrm{~h}$, is presented in Table 3 . The experimental precision evaluated through the coefficient of variation was good $(\mathrm{CV}=14.0 \%)$, similar to that obtained by Gomes et al. (2004). As the number of progenies was large, they could not be simultaneously evaluated in one same cow. To prevent confusion with other factors, progenies were separated into three groups evaluated in one same cow, with common controls, on each day. There was difference $(p \leq 0.01)$ for the variation sources cow/experiment and experiment, suggesting that the treatments had distinct behaviors on the different incubation days and in the used cows. The difference observed among cows was expected since there is genotypic variation among animals, and grain degradability may not be the same in all evaluated cows. Gomes et al. (2004) stud-

Table 3 - Summary of the variance analysis and estimates of the genetic variance among progenies $\left(\hat{\sigma}_{p}^{2}\right)$ and the heritability $\left(b^{2}\right)$ among progeny means for ruminal dry matter degradability, after 24-h incubation.

\begin{tabular}{|c|c|c|c|}
\hline Variation source & Degree of freedom & Mean square & $p$ \\
\hline Cows/experiment & 6 & 195.91 & $<0.01$ \\
\hline Experiment & 2 & 48.08 & $<0.01$ \\
\hline Check $\times$ Exp & 6 & 4.86 & 0.47 \\
\hline Treatments Adjust & 163 & 9.76 & $<0.01$ \\
\hline between genitors & 1 & 9.05 & 0.19 \\
\hline Genitors vs Progenies & 1 & 0.03 & 0.32 \\
\hline Among progenies & 157 & 10.03 & $<0.01$ \\
\hline Among prog $\mathrm{A}^{2 /}$ & 86 & 7.88 & 0.06 \\
\hline Among prog $\mathrm{B}^{2 /}$ & 70 & 12.47 & $<0.01$ \\
\hline $\mathrm{pA} v s \mathrm{pB}$ & 1 & 23.8 & $<0.01$ \\
\hline Among Check & 3 & 7.50 & 0.23 \\
\hline Check vs Prog & 1 & 0.08 & 0.06 \\
\hline Residue & 338 & 5.23 & - \\
\hline Total & 515 & 9.05 & - \\
\hline Mean & 16.3 & $\hat{\sigma}_{p}^{2}$ & $1.60(1.40-1.87)^{1 /}$ \\
\hline $\mathrm{CV}(\%)$ & 14.0 & $b^{2}$ & $46.82(31.17-59.77)^{1 /}$ \\
\hline
\end{tabular}

${ }^{1} \mathrm{LL}$ and UL - lower and upper limits of the confidence interval $(p<0.05) .{ }^{2}$ Among prog A (Cristal $\times$ Cunha); Among prog B $(\mathrm{Cunha} \times$ Cristal). 
ied RDM degradability in maize silage and also obtained a significant difference for the variation source cows.

There was no difference for the interaction controls $\mathrm{x}$ experiments. Thus, after the adjustment relative to controls, progenies were compared under similar conditions. The source of variation $\mathrm{pA}$ vs. $\mathrm{pB}$ significant indicating maternal effect degradability. Difference $(p \leq 0.01)$ was detected among treatments. In its decomposition, F-test was significant for the variation source progenies. The non-significant contrast genitors $v s$ progenies suggests that the mean development of genitors was similar to that of progenies. In addition, no difference was found for the variation source controls, i.e. although the employed genotypes had different grain types, they presented similar behavior concerning RDM degradability. This result corroborates previous data on the higher degradability of soft-endosperm maize. Flachowsky et al. (1992) observed that the RDM degradability of maize grains, $6 \mathrm{~h}$ after incubation, ranged between $35.2 \%$ and $56.9 \%$ for flint and dent grains, respectively. Verbic et al. (1995) reported that the RDM degradability of maize grains varied from $71.7 \%$ (dent) to $54.8 \%$ (flint). In a study carried out by Philippeau and Michalet-Doreau (1998), mean RDM degradability was $55.8 \%$ for dent and $42.3 \%$ for flint grains.

The comparison among hybrid cultivars or varieties of different origins and different indentation scores not always allows the conclusion that a higher RDM degradability is due to grain hardness per se. Thus, inferences about the association between grain hardness and RDM degradability is the most correct procedure since on average the endosperm constitution must be similar and the difference will only be due to grain hardness. There were differences among progenies to RDM degradability (Figure 1). In general, the means of progenies present normal distribution, indicating that additive variance predominates, especially if the number of genes involved in the trait control is not large (Ramalho et al., 2008). This statement agrees with the results reported by Gomes et al. (2004), who found predominance of additive effects when obtaining information about the genetic control of the RDM degradability of silage of maize lines.

The variation amplitude of $11.95 \%$ accounted for $73.2 \%$ of the obtained mean, indicating an expressive variation. This can be proven by estimating the genetic variance among prog-

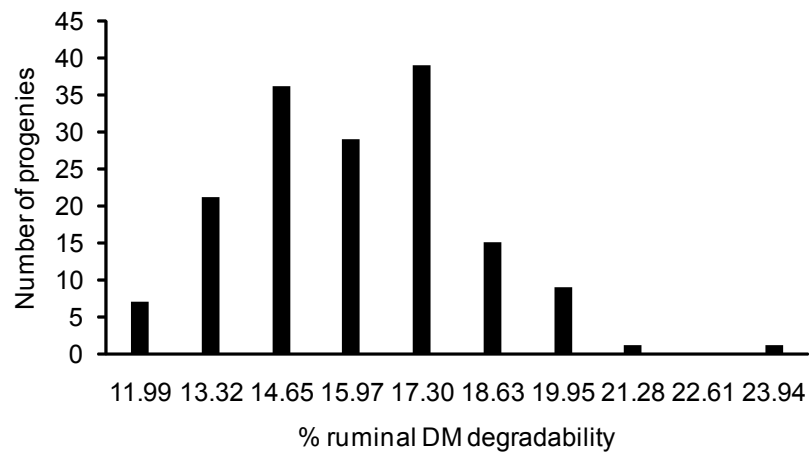

Figure 1 - Frequency distribution of ruminal dry matter (DM) degradability, during 24-h incubation, for 158 progenies. enies $\left(\hat{\sigma}_{p}^{2}\right)$, which was different from zero with $95 \%$ positive probability (Table 3 ). These results allow inferences about the potential to be explored for this characteristic through selection. There are reports on the variation among maize cultivars which, although at different magnitudes, corroborate the present results. For example, Ferret et al. (1997) obtained dry matter digestibility values ranging from 58\% to $76 \%$. Prada et al. (1999) studied the ruminal degradability of ensiled material of 49 maize hybrids and found values between $40.8 \%$ and $63.8 \%$ in 24 -hour incubation. Jaeger et al. (2006) evaluated seven hybrids as to dry matter availability and digestibility and obtained values varying from 55.3\% to $63.7 \%$. These results allow inferences about the potential to be explored for this characteristic.

The heritability estimate $\left(\mathrm{h}^{2}\right)$ was $46.8 \%$ (Table 2 ). The confidence intervals suggest that $\mathrm{h}^{2}$ is different from zero by the positive lower limit. Unfortunately, no report was found in literature on the RDM degradability of this type of progeny to compare $\mathrm{h}^{2}$ estimates. Gomes et al. (2004) obtained $h^{2}$ estimates of $80.4 \%$ for silage of maize lines. This value is almost twice the value obtained in this study. However, such estimates are not directly comparable, since they involve different products and progeny types. As regards lines, for example, twice the additive variance existent in $\mathrm{F}_{2}$ population is explored. In the present study, as the genitors were pure for grain hardness, the evaluated progenies were in $\mathrm{F}_{2: 3}$ generation, considering the endosperm, and in $\mathrm{F}_{2}$, considering the pericarp. $\mathrm{F}_{2: 3}$ progenies were used based on the premise that the endosperm constitution affects degradability. In this case, $1 \sigma_{A}^{2}+1 / 4 \sigma_{D}^{2}$ is explored, in which $\sigma_{A}^{2}$ is the additive genetic variance and $\sigma_{D}^{2}$ is the dominance genetic variance.

Another important factor to be verified is whether the association between grain indentation score and RDM degradability also occurs among progenies. Before the establishment of the experiment on degradability, progenies were visually evaluated for grain indentation score. Of the identified progenies, 21 had grade 1; 19 grade 2; 41 grade 3; 34 grade 4 ; and 43 grade 5 .

RDM degradability frequency distribution for progenies, according to the visually evaluated indentation score, is shown in Figure 2. At first, results evidenced a relationship

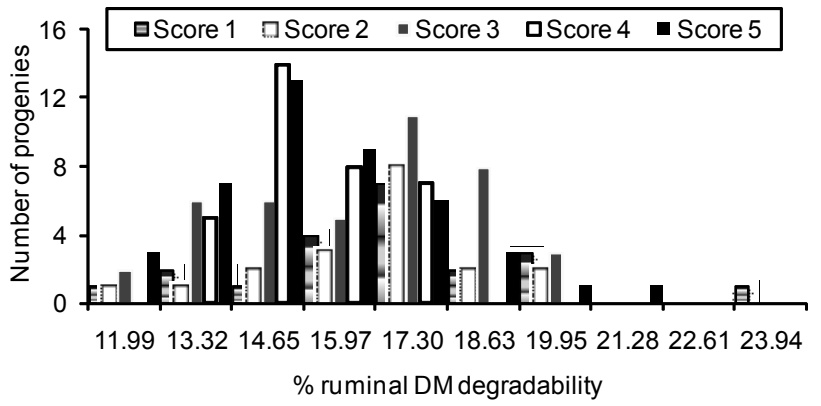

Figure 2 - Frequency distribution of ruminal dry matter (DM) degradability, during 24-h incubation, according to the visually evaluation indentation score.

Sci. Agric. (Piracicaba, Braz.), v.68, n.3, p.347-352, May/June 2011 
between indentation score and RDM degradability, since progenies with grade 1 (hard) were present in the highest RDM degradability class and those with grade 5 (soft) in lower RDM degradability classes (Figure 2). There were, for example, one progeny with visual grade 1 and RDM degradability higher than $23 \%$ and three progenies with grade 5 and RDM degradability lower than $12 \%$.

A separate comparison of the distribution frequency for each indentation score grade indicates that progenies were distributed in all RDM degradability intervals, independently of the grade (Figure 3). For progenies with grades 1 and 2, there was a higher concentration in the $16 \%$ - 17\% RDM degradability interval. The same result was observed for grade 3; however, in this case, there was a higher uniformity in the

Score 1

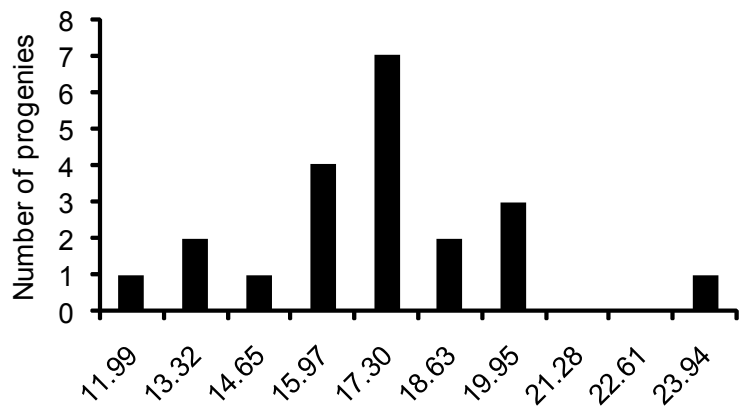

\% ruminal DM degradability

Score 3

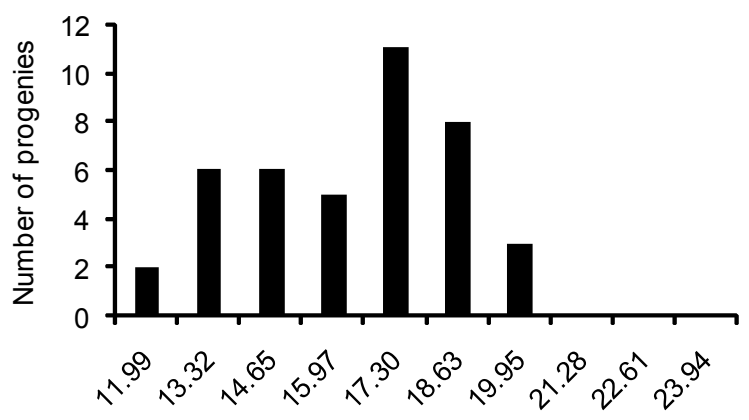

$\%$ ruminal DM degradability

Score 5

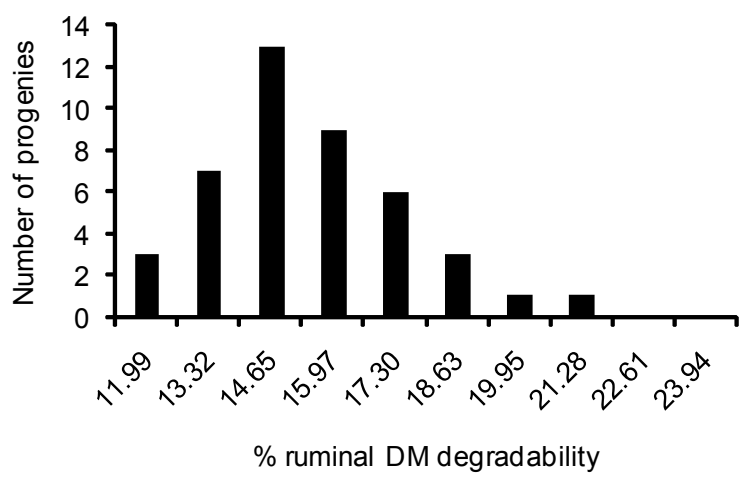

distribution of progenies. For grades 4 and 5, progenies concentrated in the 13\% - 15\% RDM degradability interval. These results differ from those existent in literature involving hybrids, as already mentioned. Similar results were reported by Rossi Júnior et al. (2006), who evaluated silage of two cultivars, a dent and a semi-flint one, at $0.20 \mathrm{~m}$ cutting height, and did not find an association between the lower hardness of visually evaluated grain and the higher degradability. Also, Ribas et al. (2007) studied dry matter in vitro digestibility of silage of four maize hybrids with different grain vitreousness degrees; for the hybrid AG1051, digestibility was 48.2\% and for SHS4040, 47.2\%. However, dent maize present higher degradability (Flachowsky et al., 1992; Philippeau and MichaletDoreau, 1998; Verbic et al., 1995).

Score 2

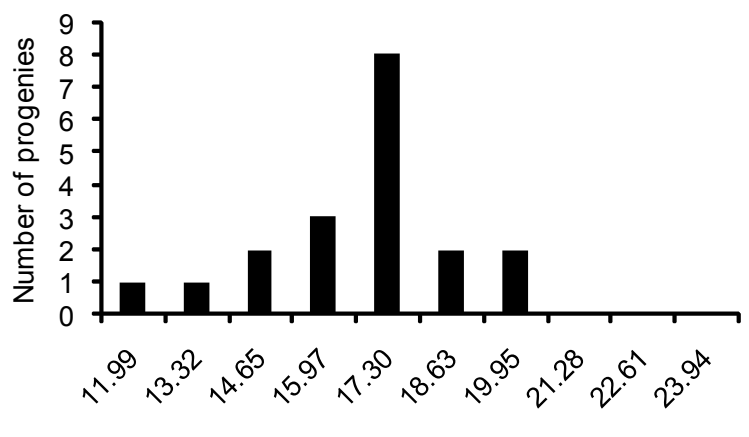

\% ruminal DM degradability

Score 4

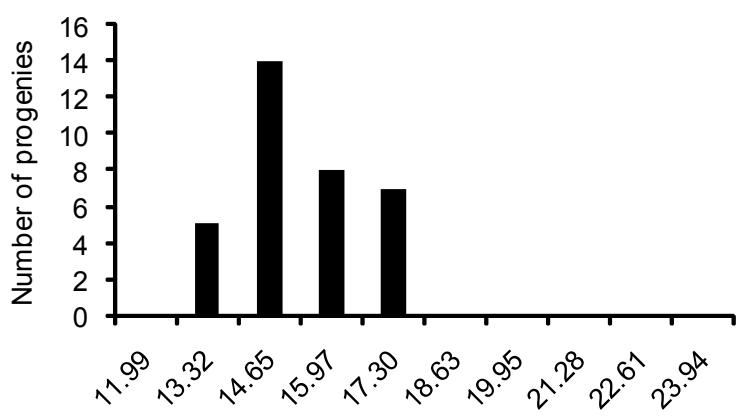

$\%$ ruminal DM degradability

Figure 3 - Frequency distribution of in situ dry matter (DM) degradability, during 24-h incubation, by indentation score. 
Seed-producing companies use the indentation score method to classify grain texture. However, this method is not efficient to associate texture with RDM degradability, since the observed aspect is that of the pericarp formed in fertilization, which corresponds to the ovary wall (Ramalho et al., 2008). Therefore, it not always reflects the real endosperm constitution which, in fact, is responsible for the higher or lower degradability. This fact is particularly expressive when a simple hybrid from the cross between two lines of different hardness is considered. In the farmer's crop, the pericarp will present the genetic constitution of $\mathrm{F}_{1}$ grains, i.e. all grains will have the same aspect; however, the endosperm and the embryo will be in $\mathrm{F}_{2}$ generation and will segregate. The visualized aspect, concerning hardness, not always reflects the real endosperm constitution. Thus, if both parental lines do not differ in hardness and endosperm, reliable results will be obtained for the association between hardness and degradability. When the grains under study are collected from experiments evaluating hybrid types, inferences are still less reliable since in this case the endosperm will have $1 / 3$ of its constitution due to pollen of unknown origin.

\section{Conclusions}

There is genetic variability for ruminal dry matter degradability of maize grains. The heritability of ruminal DM degradability indicates a possible success through selection if the evaluation of progenies is more rigorous. There is no association between the evaluation of grain indentation score and in situ dry matter degradability.

\section{Acknowledgements}

To CNPq (Conselho Nacional de Desenvolvimento Científico e Tecnológico) and to FAPEMIG (Fundação de Amparo à Pesquisa do Estado de Minas Gerais) for financial support.

\section{References}

Corrêa, C.E.S.; Pereira, M.N.; Oliveira, S.G.; Ramos, M.H. 2003. Performance of Holstein cows fed sugarcane or corn silages of different grain textures. Scientia Agricola 60: 621-629.

Cruz, C.D. 2001. Software GENES: Computational Application in Genetics and Statistic. UFV, Viçosa, MG, Brazil. 542 p. (in Portuguese).

Ferret, A.; Gasa, J.; Plaixats, J. 1997. Prediction of voluntary intake and digestibility of maize silages given to sheep from morphological and chemical composition, in vitro digestibility or rumen degradation characteristics. Animal Science 64: 493-501.

Flachowsky, G.; Baldeweg, P.; Schein, G. 1992. Anote on the in sacco dry matter degradability of variously processed maize grains and of different maize varieties in sheep. Animal Feed Science Technology 39: 173-181.

Gomes, M.S.; Von Pinho, R.G.; Ramalho, M.A.P.; Ferreira, D.V.; Brito, A.H. 2004. Genetic variability in maize lines for characteristics related to silage yield. Pesquisa Agropecuária Brasileira 39: 879885. (in Portuguese, with abstract in English).
Jaeger, S.L.; Luebbe, M.K.; Macken, C.N.; Erickson, G.E.; Klopfenstein, T.J.; Fithian, W.A. 2006. Influence of corn hybrid traits on digestibility and the efficiency of gain in feedlot cattle. Journal of Animal Science 84: 1790-1800.

Knapp, S.J.; Stroup, W.W.; Ross, W.M. 1985. Exact confidence intervals for heritability on a progeny mean basis. Crop Science Society of America 25: 192-194.

Lykos, T.; Varga, G. 1995. Effects of processing method on degradation characteristics of protein and carbohydrate sources in situ. Journal of Dairy Science 78: 1789-1801.

McAllister, T.A.; Phillippe, R.C.; Rode, L.M.; Cheng, K.J. 1993. Effect of the protein matrix on the digestion of cereal grains by ruminal microorganisms. Journal of Animal Science 71: 205-212.

Monticelli, C.J.; Menten, J.F.M.; Zanotto, D.L.; Lima, G.J.M.M.; Guidoni, A.L. 1996. Effect of particle size of corn, space allowance per animal, and sex on the performance of growing-finishing swine Revista Brasileira de Zootecnia 25: 1150-1162. (in Portuguese, with abstract in English).

Ngonyamo-Majee, D.; Shaver, R.D.; Coors, J.G.; Sapienza, D.; Lauer, J.G. 2008. Relationships between kernel vitreousness and dry matter degradability for diverse corn germplasm. II. Ruminal and postruminal degradabilities Animal Feed Science and Technology 142: $259-274$.

Passini, R.; Borgatti, L.M.O.; Ferreira, F.A.; Rodrigues, P.H.M. 2004 Degradability of differently processed corn grain in bovine rumen. Pesquisa Agropecuária Brasileira 39: 271-276. (in Portuguese, with abstract in English).

Pereira, M.N.; Von Pinho, R.G.; Bruno, R.G.; Calestine, G.A. 2004. Ruminal degradability of hard or soft texture corn grain at three maturity stages. Scientia Agricola 61: 358-363.

Philippeau, C.; Michalet-Doreau, B. 1998. Influence of genotype and ensiling of corn grain on in situ degradation of starch in the rumen. Journal of Dairy Science 81: 2178-2184.

Philippeau, C.; Landry, J.; Michalet-Doreau, B. 2000. Influence of the protein distribution of maize endosperm on ruminal starch degradability. Journal of the Science of Food and Agriculture 80: 404-408.

Prada e Silva, L.F.; Machado, P.F.; Francisco Junior, J.C. 1999. Agronomic characteristics, chemical composition and "in situ" digestibility of stover corn hybrids for silage Scientia Agraria 56: 171-184. (in Portuguese, with abstract in English).

Ramalho, M.A.P.; Santos, J.B.; Pinto, C.A.B.P. 2008. Genetic in Agriculture. UFLA, Lavras, MG, Brazil. (in Portuguese).

Ribas, M.N.; Gonçalves, L.C.; Maurício, R.M. 2007. Degradability and ruminal fermentation kinetics of four maize hybrid silages evaluated utilizing the semi-automated in vitro gas production technique. Revista Brasileira de Milho e Sorgo 6: 223-233. (in Portuguese, with abstract in English).

Rossi Júnior, P.; Fugisawa, A.C.; Schogor, A.L.B.; Muraro, G.B. 2006 Apparently digestibility of two hybrids corn, cut in different highs, submitted to silage. Archives of Veterinary Science 11: 5861. (in Portuguese, with abstract in English).

Scott, A.J.; Knott, M. 1974. A cluster analysis method for grouping means in the analysis of variance. Biometrics 30: 507-512.

Teixeira, J.C.; Santos, R.M.; Oliveira, A.I.G. 1996. Rumem degradability of dry matter, neutral detergent fibre and crude protein from rations containing cottonseed and corn in different physical forms, in holstein dairy cows. Revista Brasileira de Zootecnia 25: 814-823, (in Portuguese, with abstract in English).

Verbic, J.; Stekar, J.M.A.; Cepon, M.R. 1995. Rumen degradation characteristics and fiber composition of various morphological parts of different maize hybrids and possible consequences for breeding. Animal Feed Science and Technology 54: 133-148.

Received May 29, 2009

Accepted August 13, 2010 